\title{
Sistem Informasi Untuk Supply Chain Berkelanjutan Berbasis Pengetahuan
}

\author{
Mustafid* $^{*}$ \\ Jurusan Statistik, Fakultas Sains dan Matematika, Universitas Diponegoro, Semarang
}

Naskah Diterima : 3 September 2015; Diterima Publikasi : 1 Oktober 2015

\begin{abstract}
Information systems and supply chain has a strategic role to manage, measure and improve business performance with a sustainable competitive advantage. This paper aims to design the basic theoretical concepts of information systems for a enterprise knowledge-based sustainable supply chain. These systems in the form of a sustainable supply chain information system designed based enterprise resource knowledge and directed in accordance with the objectives and indicators of business performance in a sustainable by taking into account environmental, economic and society. Concepts theoretical basic of this system can be used as a basic for research development and application in the field of information systems and supply chain sustainability. The application of this system can be used to help management in managing and optimizing enterprise knowledge resources in accordance with the potential of the enterprise in order to improve business performance overall and sustainability.
\end{abstract}

Keywords: Sustainable Supply Chain Information Systems; Knowledge Resources; Knowledge Management; Green Supply Chain.

\begin{abstract}
Abstrak
Sistem informasi dan supply chain memiliki peran strategis untuk mengelola, mengukur dan meningkatkan kinerja bisnis dengan keunggulan kompetitif berkelanjutan. Makalah ini bertujuan untuk mendesain konsep dasar teoritik sistem informasi untuk supply chain berkelanjutan berbasis pengetahuan enterprise. Sistem ini berupa sistem informasi supply chain berkelanjutan yang didesain berdasarkan sumberdaya pengetahuan enterprise dan diarahkan sesuai dengan tujuan dan indikator kinerja bisnis secara berkelanjutan dengan memperhatikan aspek lingkungan, ekonomi dan masyarakat. Konsep dasar teoritik sistem ini dapat digunakan sebagai dasar penelitian pengembangan dan penerapan dalam bidang sistem informasi dan supply chain berkelanjutan. Penerapan dari sistem ini dapat digunakan untuk membantu manajemen dalam mengelola dan mengoptimalkan sumberdaya pengetahuan enterprise sesuai dengan potensi enterprise agar dapat meningkatkan kinerja bisnis secara menyeluruh dan berkelanjutan.
\end{abstract}

Kata kunci: Sistem Informasi Supply Chain Berkelanjutan; Sumberdaya Pengetahuan; Manajemen Pengetahuan; Green Supply Chain

\section{Pendahuluan}

Pengembangan green supply chain untuk meningkatkan kinerja bisnis yang ramah lingkungan beberapa atahun terakhir ini banyak dibahas dalam sejumlah literatur (Malviya dan Kant, 2015). Beberapa literature dalam Schaltegger (2014) juga membahas aspek penerapan supply chain berkelanjutan untuk pengukuran kinerja berkelanjutan pada supply chain. Namun masih sangat sedikit yang membahas peran sistem informasi pada green supply chain atau supply chain berkelanjutan. Sistem informasi dan supply chain memiliki peran strategis untuk membangun dan meningkatkan keunggulan kompetitif yang berkelanjutan pada enterprise. Saat ini manusia

*) Penulis korespondensi: mustafid55@yahoo.com semakin sadar perlunya hidup berkelanjutan yang ditandai dengan adanya kesadaran untuk kebutuhan hidup yang memperhatikan keseimbangan antara lingkungan, ekonomi dan masyarakat. Aktivitas manusia dalam memenuhi kehidupan telah memicu meningkatnya permintaan untuk melakukan pendekatan dengan konsep "green" atau berkelanjutan (Watson et al., 2010). Enterprise, lembaga atau organisasi semakin termotivasi untuk menerapkan program dan aktivitas berkelanjutan dalam melaksanakan kegiatan sehari-hari untuk mencapai standar hidup yang lebih baik dimasa yang akan datang.

Pembanguanan berkelanjutan didefinisikan sebagai pembangunan yang memenuhi kebutuhan saat ini tanpa mengorbankan kemampuan generasi- 
generasi mendatang untuk memenuhi kebutuhan mereka sendiri (Menlville, 2010). Definisi ini terkait dengan konsep kinerja organisasi yang terdiri dari dimensi lingkungan, ekonomi dan masyarakat. Sehingga sistem informasi berkelanjutan dapat didefinikan sebagai sistem informasi yang berkemampuan bagi organisasi dalam prakek dan proses yang meningkatkan kinerja lingkungan, ekonomi dan masyarakat (Menlville, 2010).

Saat ini persaingan produk atau jasa semakin ketat dan kompetitif, dengan pasar yang semakin selektif dalam menerima atau membeli produk atau jasa. Persaingan kualitas produk antar enterprise atau industri berkembang sangat cepat. Konsep sistem informasi dan supply chain berkelanjutan berfungsi untuk meningkatkan kinerja bisnis yang ramah lingkungan. Saat ini telah banyak penggunaan teknologi informasi untuk mendukung sistem informasi yang ramah lingkungan, misalnya penggunaan frekuensi radio identifikasi (RFID) untuk meningkatkan efektivitas enterprise melalui kemampuan berbasis informasi. Dari perspektif berkelanjutan, sistem informasi supply chain memungkinkan enterprise untuk dapat menstandarisasi, memantau, menangkap, dan memanfaatkan potensi bisnis dalam rangka miningkatkan kinerja enterprise.

Dalam mengatasi adanya faktor ketidakpastian, diperlukan manajemen pengetahuan yang dapat memanfaatkan adanya peluang dan tantangan, sehingga enterprise membutuhkan kemampuan manajemen pengetahuan dengan kemampuann manajerial yang unik, khusus dan kapasitas baru untuk dapat menangkap peluang secara berkelanjutan enterprise. Untuk melengkapi manajemen pengetahuan yang berdaya saing dan kompetitif, enterprise memerlukan upaya penerapan supply chain berkelanjutan menggunakan teknologi informasi dan komunikasi, untuk menghubungkan proses internal dan eksternal enterprise. Penggunaan teknologi informasi dalam supply chain berkelanjutan berbasis pengetahuan merupakan cara yang paling efektif untuk membuat enterprises akan lebih adaptif dan fleksibel terhadap perkembangan enterprise, baik terhadap faktor internal berupa sumberdaya material dan sumberdaya pengetahuan, serta faktor eksternal berupa tuntutan stakeholder ataupun faktor pesaing enterprise.

Kinerja intelligence bisnis dapat membantu organisasi untuk mengoptimalkan kinerja bisnis dengan mendorong penggunaan yang efektif dan efisien dari sumber daya pengetahuan. Untuk itu, sistem informasi supply chain berkelanjutan harus dapat menfaatkan kemampuan sumberdaya enterprise yang sangat strategis, yaitu sumberdaya pengetahuan yang terlibat selama proses operasi, baik didalam enterprise maupun diluar enterprise, termasuk stakeholder. Sumberdaya pengetahuan didasarkan pada kemampuan sumberdaya manusia dalam memanfaatkan sumberdaya faktor internal enterprise (material dan keuangan) dan faktor external dari tuntutan stakeholder dan pesaing enterprise. Pengukuran kinerja berkelanjutan diperlukan sebagai dasar untuk pengembangan strategi, rencana aksi, program dan kegiatan perbaikan terus-menerus. Pengukuran kinerja berkelanjutan juga digunakan untuk mengukur kinerja, memantau situasi aktual dan merencanakan perbaikan kinerja dimasa yang akan datang.

Tujuan dari penelitian ini melakukan kajian teoritik menggunakan metode pendekatan teoritik berdasarkan linteratur yang berkembang untuk desain konsep sistem informasi supply chain berkelanjutan berbasis pengetahuan yang dapat digunakan untuk meningkatkan kinerja enterprise secara menyeluruh dan berkelanjutan. Hasil pembahasan makalah ini diorientasikan untuk mendukung pembangunan berkelanjutan. Konsep dasar sistem informasi supply chain berkelanjutan berbasis pengetahun sangat diperlukan dalam berbagai bidang pengembangan dan terapan dalam membangun sistem informasi supply chain berkelanjutan. Sistem ini berperan untuk mengelola dan mengoptimalkan sumberdaya pengetahuan dalam rangka meningkatkan potensi dan kekuatan proses bisnis dalam mengelola enterprise agar dapat meningkatkan kinerja bisnis secara menyeluruh dan berkelanjutan.

\section{Metodologi}

Metode penelitian dalam desain konsep sistem informasi untuk supply chain berkelanjutan berbasis pengetahuan menggunakan metode pendekatan teoritik berdasarkan linteratur yang berkembang pada saat ini. Sistem ini berupa informasi supply chain berkelanjutan yang didesain berdasarkan sumberdaya pengetahuan dan diarahkan sesuai dengan tujuan dan indikator kinerja enterprise secara berkelanjutan dengan memperhatikan aspek lingkungan, ekonomi dan masyarakat. Sistem ini berperan untuk memfasilitasi beberapa fungsi untuk membantu proses inti pengelolaan pengetahuan, seperti proses penyimpanan, pengorganisasian, penelusuran dan transfer pengetahuan.

Desain konsep sistem informasi supply chain berkesinambungan berbasis pengetahuan diawali dengan mendesain konsep sistem informasi berkelanjutan, supply chain berbasis pengetahuan dan mengintegrasikan kedua konsep tersebut dalam sistem informasi supply chain berkelanjutan. Dalam desain konsep sistem informasi supply chain berkelanjutan berbasis pengetahuan dilakukan identifikasi terhadap berbagai pengetahuan internal yang harus dimiliki oleh enterprise sebagai sumberdaya enterprise untuk mencapai tujuan bisnis berdasarkan indikator kinerja kunci sebagai dasar indikator kinerja berkelanjutan. Desain indikator kinerja berkelanjutan dikembangkan berdasarkan 
tujuan dan ukuran-ukuran untuk merumuskan tujuan dan ukuran dalam perspektif material, finansial dan pelanggan. Ukuran kinerja bisnis ini memungkinkan perusahaan dapat memfokuskan pengukuran proses bisnis internal yang mendorong tercapainya tujuan bisnis yang ditetapkan.

Sistem informasi supply chain berkelanjutan berbasis pengetahuan mencakup berbagai nilai dalam perspektif proses bisnis internal terdiri atas tiga proses bisnis utama, yaitu inovasi, operasi, dan kontrol. Pada proses inovasi, unit bisnis meneliti kebutuhan pelanggan yang sedang berkembang atau masih tersembunyi, dan kemudian menciptakan produk atau jasa yang akan memenuhi kebutuhan tersebut. Pada proses operasi, proses operasi merupakan proses penciptaan nilai di dalam perusahaan, dimulai dengan diterimanya pesanan pelanggan dan diakhiri dengan penyampaian produk kepada pelanggan. Proses ini berfokus pada penyampaian produk kepada pelanggan secara efesien, konsisten, dan tepat waktu sesuai denga target indikator kinerja kunci.

\section{Sistem Informasi Kerberlanjutan}

Faber et al. (2005) menyatakan bahwa konsep dasar berkelanjutan dalam sistem informasi menggunakan pengetahuan, dengan urutan data informasi - pengetahuan. Data digunakan untuk membentuk informasi yang menyangkut interpretasi data. Pengetahuan dijadikan sebagai informasi yang memungkinkan manusia untuk menerapkan informasi dalam penalaran, atau melakukan tindakan pengambilan keputusan. Pengetahuan yang digunakan untuk mengoperasikan sistem informasi perlu diperbarui terus menerus. User yang mengontrol sistem informasi harus mengatasi perubahan sistem untuk mempertahankan keseimbangan antara sistem dan lingkungan dalam rangka membangun keseimbangan yang tepat dari semua proses pengetahuan yang mengarah ke pengetahuan berkelanjutan. Dalam hal ini sistem informasi harus dapat memungkinkan melibatkan aspek penciptaan pengetahuan, evaluasi kritis pengetahuan, dan memastikan integrasi yang efektif dan penerapan pengetahuan.

Pendekatan adaptasi juga merupakan konsep dasar berkelanjutan, yaitu bahwa enterprise perlu memastikan dapat berinteraksi dengan lingkungan yang sesuai dengan kebutuhan lingkungan (Faber et al., 2005). Sistem informasi sebagai alat harus dapat menyesuaikan dengan adanya perubahan lingkungan. Dalam hal ini sistem informasi berkelanjutan merupakan sistem informasi yang dapat menyesuaikan dengan lingkungan, melibatkan stakeholder terkait, dan mendukung siklus pengetahuan, yaitu penciptaan, evaluasi dan integrasi pengetahuan. Dengan demikian aspek pembelajaran (learning) menjadi sangat esensial dalam sistem informasi berkelanjutan (Maruster et al., 2008). Sistem informasi terus mengalami perubahan sesuai dengan tuntutan dan kebutuhan masyarakat dan lingkungan. User yang berperan mengendalikan sistem informasi harus dapat menyesuaikan perilaku lingkungan dengan memperoleh pengetahuan baru. Pengetahuan baru yang dihasilkan diadopsi dalam sistem, sehingga user dapat memasukkan pengetahuan baru sesuai dengan perilaku masyarakat dan lingkungan. Pengetahuan yang digunakan untuk mengoperasikan sistem informasi perlu diperbaharui dan disesuaikan secara terus menerus dengan memperhatikan keseimbangan antara sistem informasi dan lingkungan.

Desain konsep sistem informasi berkelanjutan dimulai dengan mengetahui hubungan antara perilaku manusia dan isu-isu berkelanjutan yang dikonseptualisasikan menggunakan gagasan kecerdasan buatan. Kecerdasan buatan didefinisikan sebagai sistem yang dibuat oleh manusia dan dioperasikan oleh manusia. Demikian juga sistem informasi diperlakukan sebagai sistem buatan yang merupakan buatan manusia dan dioperasikan oleh manusia. Dari definisi kecerdasaan buatan dan mengingat bahwa tindakan manusia mengikuti dari pengetahuan, maka sumberdaya pengetahuan dapat diidentifikasi untuk mengontrol kecerdasan buatan.

Penerapan sistem informasi berkelanjutan mengacu pada inisiatif yang secara langsung atau tidak langsung untuk menangani kelestarian lingkungan dalam enterprise yang melibatkan aktivitas proses dan kelembagaan bertujuan untuk meningkatkan kinerja bisnis dengan memperhatikan keseimbangan lingkungan, ekonomi dan masyarakat/masyarakat. Perkembangan penerapan sistem informasi diberbagai bidang telah dapat memberikan kontribusi strategis untuk pengetahuan dengan konsep green atau berkelanjutan. Sudah banyak penelitian sistem informasi berorientasi pada inovasi pelestarian lingkungan yang bertujuan untuk untuk menghasilkan rekayasa dan evaluasi sistem yang berorientasi pada tanggung jawab perbaikan lingkungan dan pelestarian alam.

Sistem informasi berkelanjutan dapat didesain untuk mengurangi dampak negatif penggunaan teknologi informasi terhadap lingkungan, atau secara tidak langsung penggunaan sistem informasi dapat mendukung inisiatif bisnis dalam mengurangi dampak negatif lingkungan. Komponen green sistem informasi dan green teknologi informasi dapat dibedakan berdasarkan pada dampaknya terhadap lingkungan. Green teknologi informasi berkenaan konsumsi energi dan limbah yang berhubungan dengan penggunaan perangkat keras dan perangkat lunak yang cenderung memiliki dampak langsung (Melville, 2010). Sebagai contoh dalam meningkatkan efisiensi energi perangkat keras untuk pusat data, konsolidasi server menggunakan perangkat lunak virtualisasi, dan mengurangi limbah 
yang berhubungan dengan peralatan perangkat keras dan perangkat lunak (Watson, 2010). Sedangkan pada green sistem informasi mengacu pada pengembangan dan penggunaan sistem informasi untuk mendukung atau mengaktifkan inisiatif berkelanjutan yang ramah lingkungan.

Sebagai contoh misalnya pada penggunaan green sistem informasi menggunakn teknologi informasi adalah teleconference yang memungkinkan penyenggaraan rapat, pelatihan atau diskusi jarak jauh yang mengurangi dampak lingkungan negatif yang terkait dengan perjalanan. Sistem informasi lingkungan dapat untuk melacak dan memantau variabel lingkungan seperti limbah, emisi, toksisitas, dan konsumsi air. Pada sistem informasi supply chain juga dapat digunakan untuk mengoptimalkan transportasi dan rute bahan baku dan produk, sehingga mengurangi jumlah energi pada aliran proses dan produk (Watson, 2010).

Dalam berbagai riset tentang green sistem informasi, peneliti sistem informasi menyelidiki bagaimana kekuatan transformatif sistem informasi yang dapat dimanfaatkan untuk menciptakan kondisi masyarakat yang berkelanjutan secara ekologis (Watson, 2010). Dalam konteks ini, gagasan green sistem informasi telah muncul sebagai desain dan implementasi sistem informasi yang berkontribusi terhadap proses bisnis yang berkelanjutan. Peran pengembangan sistem informasi, memberikan kontribusi untuk mendorong aspek manajemen operasional dengan melibatkan peran proses bisnis dalam rangka menciptakan masyarakat sadar ramah lingkungan.

Banyak pelaku bisnis menghubungkan program berkelanjutan dengan strategi enterprise. Para manajer menyadari bahwa enterprise memiliki tanggung jawab utama untuk berpartisipasi dalam memecahkan masalah global berorientasi pada pelanggan yang mengharapkan penyediaan green produk dan jasa. Dalam hal ini, kesinambungan memerlukan praktek bisnis yang berkelanjutan karena peran dominan enterprise dalam ekonomi global, dan sistem informasi akan menjadi peralatan utama dalam transisi menuju ekonomi berkelanjutan.

Sistem informasi berkelanjutan mengacu pada desain dan implementasi sistem informasi yang berkontribusi terhadap proses bisnis yang berkelanjutan. Melville (2010) memberikan beberapa contoh peran sistem informasi berkelanjutan :

a. Mengurangi biaya transportasi dengan sistem manajemen armada dan rute dinamis kendaraan untuk menghindari kemacetan lalu lintas dan mengurangi konsumsi energi

b. Dukungan team work dan pertemuan ketika pegawai didistribusikan ke berbagai daerah atau negara, sehingga dapat mengurangi dampak perjalanan dinas.

c. Melacak informasi lingkungan (seperti keracunan, energi yang digunakan, air yang digunakan, dll) tentang penciptaan produk, komponen mereka, dan pemenuhan layanan

d. Memantau emisi operasional enterprise dan produk-produk limbah untuk mengelola mereka lebih efektif.

e. Memberikan informasi kepada konsumen sehingga mereka dapat membuat pilihan green yang lebih nyaman dan efektif.

Penerapan sistem informasi dalam pembangunan berkelanjutan sudah semestinya tidak dilihat dari aspek biaya saja untuk melakukan bisnis. Namun sebaliknya sistem informasi berkelanjutan dapat mempunyai kesempatan dalam enterprise untuk dapat meningkatkan produktivitas, mengurangi biaya, dan meningkatkan profitabilitas melalui keseimbangan dengan lingkungan. Lingkungan yang buruk sering kali menghasilkan berbagai bentuk limbah. Sumber daya yang tidak terpakai, inefisiensi energi, kebisingan, panas, dan emisi adalah semua produk limbah yang mengurangi dari efisiensi ekonomi. Limbah yang sedikit berarti enterprise lebih efisien. Enterprise yang aktif menggunakan green sistem informasi, dapat menciptakan praktek bisnis yang berkelanjutan melakukan hal yang benar bagi komunitas mereka, pelanggan, investor, dan generasi masa depan.

\section{Supply chain berbasis pengetahuan}

Dalam era globalisasi dan persaingan bisnis, enterprise harus dapat meningkatkan kapasitas kewirausahaan bidang manajemen dan sumberdaya manusai dalam rangka mengembangkan, membangun, melindungi, mentransfer dan mengintegrasikan pengetahuan. Integrasi supply chain berbasis pengetahuan harus melibatkan faktor internal dan external, dan secara khusus harus memperhatikan pengetahuan pelanggan, pemasok, dan pesaing. Supply chain berbasis pengetahuan harus dapat menekankan proses akuisisi dan berbagi pengetahuan dalam organisasi. Aktivitas utama dalam supply chain berbasis pengetahuan meliputi akuisisi, seleksi, generasi, internalisasi, dan eksternalisasi. Aktivitas utama ini merupakan penempatan rantai pengetahuan internal berdasarkan pengetahuan dari lingkungan eksternal terkait pengetahuan pelanggan, pemasok, dan pesaing untuk meningkatkan daya saing enterprise.

Untuk meningkatkan daya saing enterprise, enterprise harus mempertahankan dan memanfaatkan pengetahuan internal dan eksternal dalam bentuk nilai pengetahuan enterprise. Pengetahuan dapat berasal dari aset tidak berwujud, seperti pengetahuan sumber daya manusia, disamping dari nilai tambah yang ada pada enterprise. Pengetahuan menjadi aset utama untuk mendukung peningkatkan produktifitas dan inovasi dari aspek peralatan, modal, bahan baku dan tenaga kerja untuk. Keunggulan kompetitif enterprise sebagian besar berasal dari penciptaan 
pengetahuan dan inovasi secara berkelanjutan. Sehingga sumber daya pengetahuan pada enterprise tidak hanya sebagai kompetensi inti dalam enterprise, tetapi juga merupakan elemen kunci untuk bersaing. Dengan demikian, supply chain berbasis pengetahuan yang efektif menjadi faktor penting dalam bisnis modern, dan menjadi fondasi dasar untuk menciptakan dan mempertahankan kemampuan kompetensi inti enterprise.

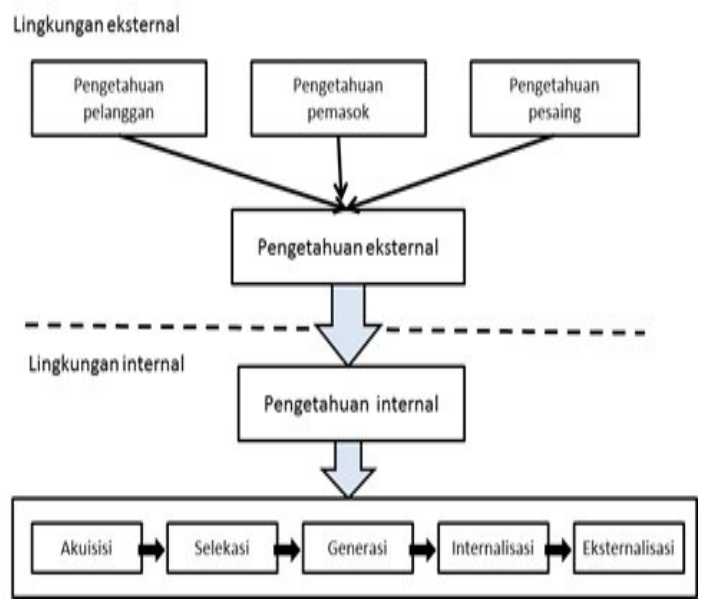

Gambar 1. Kerangka model rantai pengetahuan (Sumber : Tseng, 2009)

Enterprise saat ini dihadapkan pada kompetensi lokal dan global. Manajer puncak harus meninjau lingkungan internal dan eksternal dalam rangka untuk memahami kekuatan, kelemahan, peluang, dan ancaman enterprise yang dijadikan sebagai strategi dalam menjalankan supply chain berbasis pengetahuan. Enterprise harus mampu membuat keputusan yang cerdas berdasarkan informasi yang didapat dalam rangka mengembangkan kapabilitas inti yang dinamis untuk lebih mengenali dan memanfaatkan setiap peluang bisnis. Namun demikian, belum sepenuhnya memahami bagaimana manajer menyerap informasi dan mengubahnya menjadi pengetahuan enterprise selama interaksi mereka dengan lingkungan eksternal terjadi.

Kerangka supply chain berbasis pengetahuan didasarkan pada lima kekuatan yang mempengaruhi enterprise (Tseng, 2009), yaitu persaingan kompetitif dalam industri, ancaman dari pendatang baru, ancaman produk pengganti, daya tawar pelanggan, daya tawar pemasok (Gambar 1). Kerangka ini menggunakan analisis berdasarkan pengetahuan eksternal dengan memasukkan lima kekuatan yang mempengaruhi, yaitu persaingan kompetitif dalam pengetahuan bidang yang sama, ancaman pengetahuan baru, ancaman pengetahuan pengganti, dan pengetahuan konsumen dan pemasok. Dalam rangka untuk mengurangi kompleksitas analisis, pengetahuan terkait persaingan kompetitif, ancaman pendatang pengetahuan baru dan pengetahuan pengganti diklasifikasikan sebagai pengetahuan pesaing. Oleh karena itu, tiga aspek utama sumber pengetahuan meliputi pengetahuan pelanggan, pemasok, dan pesaing.

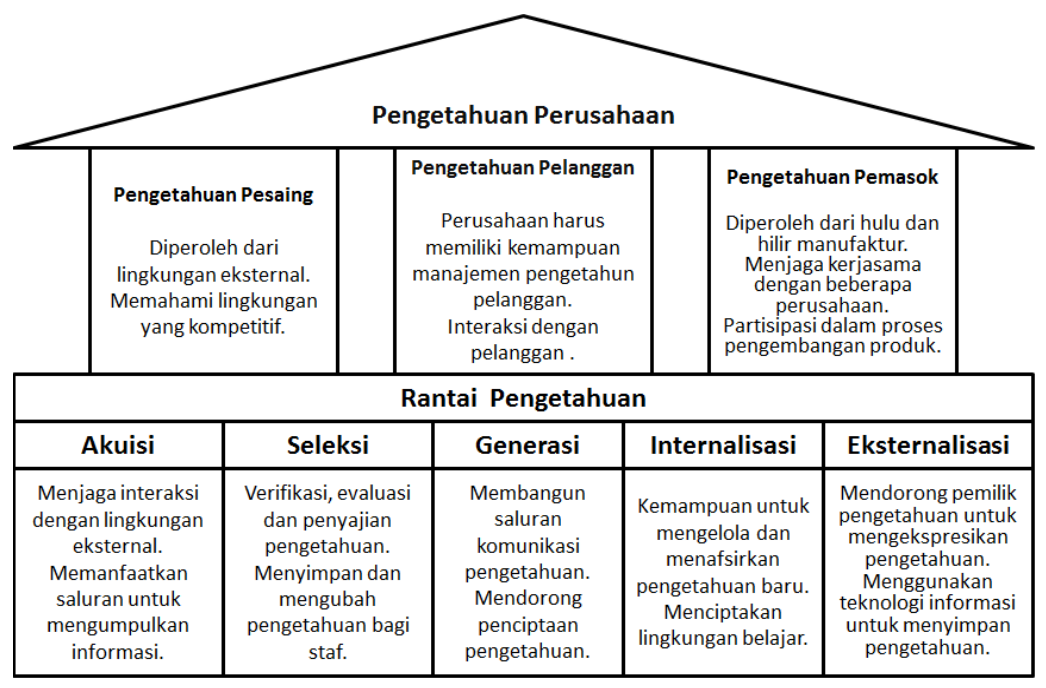

Gambar 2. Kerangka pengetahuan enterprise (Sunber : Tseng, 2009)

Penerapan model supply chain berbasis pengetahuan menggambarkan bagaimana pengetahuan memiliki nilai pengetahuan yang tinggi bagi enterprise yang diperoleh melalui lima aktivitas utama, yaitu akuisisi, seleksi, generasi, internalisasi, dan eksternalisasi (Gambar 2). Lima aktivitas tersebut dapat mengubah pengetahuan pelanggan, pemasok, pesaing untuk program aktivitas bertujuan meningkatkan daya saing enterprise. Kerangka pengetahuan pada perusahaan diberikan pada Gambar 2, yang menunjukkan bahwa pengetahuan enterprise didukung oleh infrastruktur untuk 
pengetahuan pelangan, pemasok, dan pesaing. Selanjutnya, enterprise menggunakan lima aktivitas utama rantai pengetahuan untuk mendapatkan pengetahuan pelanggan, pemasok, dan pesaing untuk meningkatkan daya saing.

Model rantai pengetahuan mengidentifikasi dan mencirikan aktivitas manajemen pengetahuan yang harus fokus pada pencapaian peningkatan daya saing. Aktivitas manajemen pengetahuan dibagi menjadi lima aktivitas utama, yaitu akuisisi pengetahuan, seleksi, generasi, internalisasi dan eksternalisasi, dan empat aktivitas pendukung meliputi pengetahuan kepemimpinan, koordinasi, kontrol dan pengukuran. Dengan menggunakan model rantai pengetahuan, analisis aktivitas dan sumber daya yang dibutuhkan untuk melakukan operasi manajemen pengetahuan akan dibuat lebih fleksibel, dan lebih mampu untuk meningkatkan keunggulan kompetitif.

Kerangka kerja konseptual untuk menyelidiki bagaimana enterprise menerapkan pengetahuan rantai aktivitas internal untuk mendapatkan pengetahuan eksternal, serta bagaimana menyaring, menyingkat, mengubah pengetahuan untuk meningkatkan keunggulan kompetitif yang berkelanjutan. Selain itu, dengan memanfaatkan model rantai pengetahuan dapat menganalisi dampak dari pengetahuan pelanggan, pemasok dan pesaing. Berikut diberikan deskripsi pengetahuan sebagai input utama sistem informasi supply chain berbasis pengetahuan (Tseng, 2009).

Pengetahuan pelanggan. Pengetahuan pelanggan merupakan aset tidak berwujud yang angat penting bagi enterprise, karena memungkinkan pelanggan menjadi pelanggan yang loyal, yaitu pelanggan yang dapat bertransaksi kembali dan memberikan nilai tambah bagi enterprise. Dengan pengetahuan pelanggan, enterprise dapat memperoleh pemahaman yang menyeluruh tentang kebutuhan pelanggan sesuai dengan kemampuan enterprise. Enterprise harus membangun database pengetahuan serta mengembangkan mekanisme untuk akuisisi, kontrol, dan publikasi informasi yang dikandungnya.

Pengetahuan pelanggan dapat dibedakan menjadi dua, yaitu pertama pengetahuan tentang keakraban pelanggan, yang berarti jumlah akumulasi pengalaman oleh pelanggan tentang produk. Kedua adalah kemampuan pelanggan sebagai pengguna produk. Ketika pelanggan lebih akrab dengan layanan, mereka akan memiliki lebih percaya diri atau kemampuan untuk menguji kualitas layanan, dan kemudian mulai memiliki harapan tentang kualitas pelayanan di masa depan. Jika pelanggan memiliki pengetahuan yang berkaitan dengan produk dan layanan, pelanggan akan mengubah cara berpikir, berkomunikasi dan berperilaku. Mereka juga akan menyimpan pengetahuan ini sebagai standar untuk mengevaluasi kualitas masa depan. Dengan demikian, dalam rangka untuk memperkuat hubungan dengan pelanggan, enterprise harus meningkatkan kualitas informasi pelanggan sehingga dapat memperoleh gambaran yang jauh lebih handal dari perilaku pelanggan.

Peningkatan interaksi dengan pelanggan sangat membantu untuk lebih menyerap pengetahuan pelanggan. Hal ini juga dapat disimpulkan bahwa pengetahuan pelanggan menjadi informasi, kemudian ditransfer menjadi pengetahuan yang bernilai tinggi. Manajemen pengetahuan tidak hanya fokus pada isuisu internal, seperti penciptaan dan berbagi pengetahuan, juga fokus pada pengetahuan pelanggan sebagai pengetahuan eksternal, seperti pasar bagi pelanggan Dengan demikian, ketika enterprise menngumpulkan informasi data pelanggan, perdagangan, preferensi, dan sebagainya, informasi ini harus secara sistematis terorganisir, dan dijadikan sebagai pengetahuan komunikatif pelanggan.

Pengetahuan pemasok. Keberhasilan inovasi sangat berkaitan dengan penggunaan pengetahuan dan teknologi, serta hubungan dengan pelanggan dan pemasok. Pengetahuan pemasok yang paling utama adalah pengetahuan tacit yang terletak pada percakapan dan interaksi antara manajer dengan pemasok. Model penciptaan pengetahuan didasarkan pada interaksi dinamis antara pemasok dan enterprise, dan diasumsikan bahwa enterprise dapat mengintegrasikan produk, pasar, dan model menciptakan pengetahuan. Pemanfaatan percakapan langsung antara enterprise dengan pemasok bertujuan untuk menemukan pengetahuan baru terkait dengan sumber daya pasokan. Oleh karena itu, harus ada saluran yang dapat diandalkan bagi semua pihak dalam bisnis yang dapat bertukar pikiran dan berkomunikasi dengan satu sama lain sehingga enterprise dapat lebih efektif mendapatkan pengetahuan tacit yang dipertukarkan.

Pengatahuan pemasok digunakan untuk membantu proses pengambilan keputusan dengan menghubungkan permintaan pelanggan dengan kemampuan pemasok, sehingga biaya persediaan dapat diminimalkan. Untuk menyediakan produk yang memenuhi atau melebihi harapan pelanggan, enterprise harus mengetahui segmen pelanggan sesuai yang mereka targetkan. Selain itu, pelanggan secara alami ingin tahu tentang produk yang disediakan oleh enterprise lain. Partisipasi pemasok dalam tahap awal pengembangan produk baru memiliki pengaruh yang signifikan terhadap hasil yang sukses dari proyek. Pada tahap awal pengembangan produk dengan menerapkan strategi pemasaran yang relevan untuk memastikan pendapat dari pelanggan dan pemasok, proses desain dalam rangka untuk meningkatkan pengembangan produk harus memperhatikan dalam optimalisasi biaya mengurangi waktu yang dibutuhkan.

Pengetahuan pesaing. Enterprise harus dapat menggunakan strategi bisnis untuk menghadapi kompetisi global dan local untuk mendapatkan manfaat dari pesaing sebagai sumber informasi 
melalui benchmarking dan transfer praktek terbaik, serta pengetahuan pesaing yang terdiri dari kemampuan kunci enterprise saingan. Ketepatan waktu dan keakuratan melihat pesaing menentukan kemampuan enterprise untuk menanggapi langkah kompetitif dalam bisnis global. Enterprise dengan memahami kompetensi pengetahuan pelanggan dan kompetensi pengetahuan pesaing, berarti enterprise tersebut memiliki kemampuan untuk memperoleh, menginterpretasikan dan mengintegrasikan informasi tentang lingkungan global yang kompetitif. Oleh karena itu pengetahuan pesaing merupakan salah satu kompetensi pengetahuan pasar yang dibutuhkan untuk mencapai sukses enterprise untuk meningkatkan kinerja enterprise. Manajer harus memiliki pemahaman yang menyeluruh tentang enterprise pesaing, serta tetap waspada untuk mengidentifikasi ancaman-ancaman dan peluang di pasar.

Rantai pengetahuan. Potensi sumber keunggulan kompetitif ada di mana-mana pada lingkungan enterprise. Keunggulan kompetitif akan tumbuh secara fundamental dari nilai enterprise yang mampu menciptakan nilai bagi pelanggan, Model value chain terdiri melibatkan berbagai aktivitas nilai tambah. Aktivitas nilai tambah ini membentuk sebuah jembatan antara formulasi strategi bersaing dan implementasi. Selain itu, value chain enterprise biasanya terhubung dengan value chain nilai pemasok, jaringan, dan klien, yang kemudian menjadi value chain bisnis. Setiap enterprise dapat menerapkan model value chain untuk menganalisis bagaimana mengurangi biaya atau mengembangkan langkah strategis. Enterprise juga dapat melakukan analisis keterkaitan value chain antara pemasok, produsen dan klien untuk menemukan cara-cara peningkatan daya saing.

\section{Sistem informasi supply chain berkelanjutan}

Dalam perspektif lingkungan, gagasan green identik dengan berkelanjutan (Watson et al. 2010). Green supply chain didefinisikan sebagai integrasi pemikiran ramah lingkungan ke dalam supply chain, meliputi desain produk, sumber dan seleksi bahan baku, proses manufaktur, distribusi produk akhir ke konsumen. Green manajemen supply chain merupakan manajemen dengan pendekatan lingkungan yang bertujuan untuk mengurangi atau meminimalkan dampak negatif lingkungan seperti polusi, pemborosan sumber daya, dan produk pembuangan (Melville, 2010). Hal ini bertujuan juga untuk membantu meningkatkan kinerja green supply chain dalam memenuhi peraturan lingkungan yang ada (Azevedo, 2011).

Sistem informasi supply chain berkelanjutan berperan pada pemeliharaan dan pengembangan produk, proses produksi, layanan atau penggunaan teknologi/sistem informasi secara berkelanjutan untuk mewujudkan visi dan misi enterprise. Komponen dasar pada model supply chain berkelanjutan terdiri dari supply chain material dan supply chain pengetahuan (Du Preez and Low, 2007). Supply chain material berlaku untuk proses produksi dan pengembangan produk, serta menunjukkan bagaimana perihal rekayasa, manufaktur dan nilai pelanggan yang terkait dalam proses pembuatan produk, mulai dari konsep manufaktur, proses produksi hingga penggunaan produk dan unpan balik dari pelanggan (Gambar 3). Aliran kontinyu informasi dan pengetahuan meliputi informasi tentang produk, manufaktur dan pemanfaatan informasi untuk rekayasa, manufaktur dan pelanggan yang terlibat.

Sistem informasi supply chain berkelanjutan berbasis pengetahuan merupakan pembangkit bagi value chain pengetahuan. Hal ini menunjukkan bagaimana aliran informasi dan pengetahun dapat menemukan pengetahuan baru, mengkonversi dari tacit ke eksplisit, mentransfer pengetahuan melalui dokumentasi dan staf ke staf, dan akhirnya menerapkan pengetahuan tersebut dalam operasional enterprise dengan supply chain material (Gambar 3). Adanya informasi dan pengetahuan dari masyarakat, dan banyaknya permintaan menjadi sumberdaya pengetahuan dalam supply chain pengetahuan untuk peningkatan berbagai inovasi baru.

Penerapan sistem informasi supply chain berkelanjutan pada peningkatan kinerja proses bisnis memerlukan pengetahuan berbagai bidang, seperti bidang manajemen proses bisnis yang menyangkut perbaikan terus-menerus dan dasar inovasi pada proses bisnis untuk meningkatkan efisiensi dan efektivitas enterprise. Manajemen proses bisnis memanfaatkan teknologi/sistem informasi untuk merancang sosio-teknis kerja sistem, termasuk desain berdasarkan isu yang berhubungan dengan bisnis dan sumberdaya manusia. Manajemen proses bisnis dibangun sebagai pendekatan manajemen yang komprehensif membantu enterprise untuk beroperasi dan mencapai tujuan bisnis enterprise, yang berhubungan dengan logistik, manufaktur, jasa keuangan, kesehatan, pendidikan, atau lainnya yang berhubungan dengan enterprise.

Sistem informasi supply chain berkelanjutan berbasis pengetahuan merupakan pembangkit bagi value chain pengetahuan. Hal ini menunjukkan bagaimana aliran informasi dan pengetahun dapat menemukan pengetahuan baru, mengkonversi dari tacit ke eksplisit, mentransfer pengetahuan melalui dokumentasi dan staf ke staf, dan akhirnya menerapkan pengetahuan tersebut dalam operasional enterprise dengan supply chain material (Gambar 3). Adanya informasi dan pengetahuan dari masyarakat, dan banyaknya permintaan menjadi sumberdaya pengetahuan dalam supply chain pengetahuan untuk peningkatan berbagai inovasi baru. 


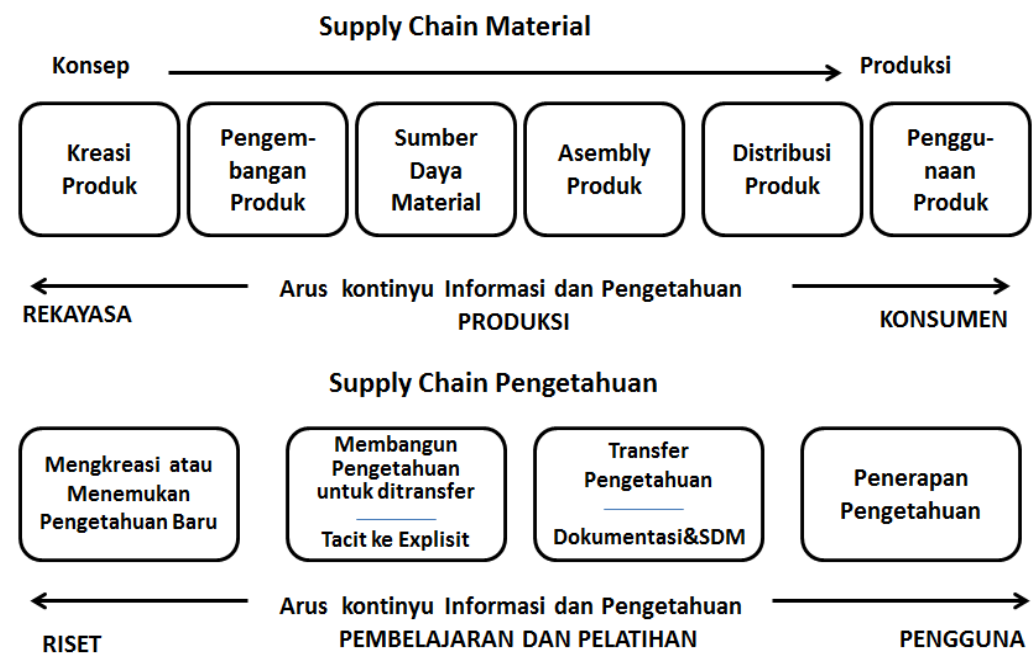

Gambar 3. Model supply chain material dan informasi (Sumber : Du Preez and Low, 2007)

Sistem informasi supply chain berkelanjutan berbasis pengetahuan merupakan pembangkit bagi value chain pengetahuan. Hal ini menunjukkan bagaimana aliran informasi dan pengetahun dapat menemukan pengetahuan baru, mengkonversi dari tacit ke eksplisit, mentransfer pengetahuan melalui dokumentasi dan staf ke staf, dan akhirnya menerapkan pengetahuan tersebut dalam operasional enterprise dengan supply chain material (Gambar 3). Adanya informasi dan pengetahuan dari masyarakat, dan banyaknya permintaan menjadi sumberdaya pengetahuan dalam supply chain pengetahuan untuk peningkatan berbagai inovasi baru.

Penerapan sistem informasi supply chain berkelanjutan pada peningkatan kinerja proses bisnis memerlukan pengetahuan berbagai bidang, seperti bidang manajemen proses bisnis yang menyangkut perbaikan terus-menerus dan dasar inovasi pada proses bisnis untuk meningkatkan efisiensi dan efektivitas enterprise. Manajemen proses bisnis memanfaatkan teknologi/sistem informasi untuk merancang sosio-teknis kerja sistem, termasuk desain berdasarkan isu yang berhubungan dengan bisnis dan sumberdaya manusia. Manajemen proses bisnis dibangun sebagai pendekatan manajemen yang komprehensif membantu enterprise untuk beroperasi dan mencapai tujuan bisnis enterprise, yang berhubungan dengan logistik, manufaktur, jasa keuangan, kesehatan, pendidikan, atau lainnya yang berhubungan dengan enterprise.

Sistem informasi supply chain berkelanjutan harus memenuhi ketentuan lingkungan dan dapat meningkatkan konsistensi dan mutu produk, mengurangi biaya produk dan meningkatkan produktivitas sumber daya (Srivastava, 2011). Hal ini menunjukkan bahwa supply chain berkelanjutan dibutuhkan dalam pelaksanaan praktek green manajemen supply chain dalam rangka memenuhi ramah lingkungan enterprise dan juga meningkatkan nilai tambah enterprise. Green supply chain berhubungan dengan green teknologi atau proses, meliputi inovasi dalam teknologi seperti hemat energi, daur ulang limbah, desain produk hijau atau pengelolaan lingkungan enterprise (Chen et al. (2008). Dengan demikian, green supply chain merupakan pendekatan lingkungan, ide, produk, proses atau jasa yang menyangkut aspek meminimalkan dampak negatif terhadap lingkungan dan juga membuat diferensiasi produk yang dikembangkan antara pesaing.

Pada penerapan inovasi dalam supply chain berkelanjutan dikategorikan menjadi empat jenis inovasi dalm green supply chain, yaitu inovasi produk, inovasi proses, inovasi manajerial, pemasaran dan inovasi. Green inovasi digunakan untuk meningkatkan kinerja pengelolaan lingkungan dalam rangka memenuhi persyaratan peraturan lingkungan. Pengelolaan lingkungan di sini adalah merujuk kepada green manajemen supply chain yang diimplementasikan dalam operasi bisnis. Dukungan dan komitmen dari manajemen puncak memainkan peran kunci dalam pelaksanaan pengelolaan lingkungan internal yang sukses.

Sistem informasi supply chain berkelanjutan memberikan cara pencarian terus menerus secara berinovasi pada setiap tahap supply chain untuk mendapatkan keunggulan kompetitif dan mengurangi masalah lingkungan disepanjang mata rantai supply chain dalam sistem informasi. Konsep dasar supply chain berkelanjutan mendasari praktik sistem informasi supply chain berkelanjutan dan mendasari komitmen pemasok dalam pengembangan green produk dalam rangka meningkatkan keunggulan kompetitif dan kinerja lingkungan.

Komitmen manajemen dalam pasokan di setiap mata rantai merupakan aspek penting dalam 
penggunaan sistem informasi supply chain berkelanjutan, dimana komitmen pemasok diperlukan dalam memberikan bahan baku manufaktur yang memenuhi persyaratan lingkungan. Sistem informasi supply chain berkelanjutan mendasari pelestarian dan pengembangan green produk yang lebih strategis dan ramah lingkungan, dalam pengertian dapat mengurangi dampak ekologis aktivitas industri tanpa mengorbankan mutu, biaya, keandalan, kinerja atau efisiensi pemanfaatan energi. Konsep ini melibatkan pergeseran paradigma untuk memenuhi peraturan lingkungan dengan situasi tidak hanya meminimalkan kerusakan ekologis, tetapi juga mengarah pada keuntungan ekonomi secara keseluruhan (Srivastava, 2007).

Manajemen dan pengukuran kinerja pada sistem informasi supply chain berkelanjutan memerlukan kejelasan rincian berbagai aspek pada setiap proses mata rantai supply chain, dan dan tujuan dengan kriteria yang dapat diukur. Prioritas utama sistem pengukuran kinerja berkelanjutan berorientasi pada aspek untuk mengukur, berkomunikasi dan mengurangi jumlah dampak negatif terhadap lingkungan dan masyarakat yang dan berkontribusi untuk transformasi berkelanjutan bagi konsumen dan masyarakat. Hal ini juga termasuk pertimbangan terhadap risiko berkelanjutan dan peluang dari supply chain ada.

Ada tiga strategi berkelanjutan yang dapat diterapkan untuk meningkatkan peran sistem informasi supply chain keberlajutan, yaitu penerapan efisiensi, konsistensi dan kecukupan (Schaltegger, 2014). Pertama, pendekatan efisiensi dalam konteks berkelanjutan dipandu dengan prinsip menciptakan nilai ekonomi dengan dampak masyarakat dan lingkungan negatif yang lebih rendah. Kedua, pendekatan konsistensi yaitu untuk mengganti bahan yang tidak ada aspek berkelanjutan dengan bahan yang konsisten dengan alam (ramah lingkungan), yaitu bahan yang ditemukan pada ekosistem secara alami. Ketiga adalah pendekatan kecukupan didasarkan pada kenyataan bahwa setiap produk yang tidak harus diproduksi tidak akan menyebabkan kerusakan dan tidak akan memerlukan supply chain dengan dampak berbahaya. Manajemen supply chain dipandu oleh prinsip-prinsip kecukupan berfokus eliminasi. Dalam penerapa sistem informasi supply chain berkelanjutan. Pada penerapanyya ketiga strategi pendekatan berkelanjutan tersebut dapat dikombinasikan satu dengan yang lain.

\section{Kesimpulan}

Sistem informasi untuk supply chain berkelanjutan berbasis pengetahun memiliki potensi besar untuk menangani permasalahan dampak negatif lingkungan, ekonomi dan masyarakat dengan melibatkan seluruh aspek sumber daya yang dimiliki enterprise. Aspek berkelanjutan pada sistem ini berkaitan dengan sistem pembelajaran bagi enterprise dengan pendekatan pengetahuan, ide atau teknologi/ sistem informasi dalam pemeliharaan, penerapan dan pengembangan sistem informasi supply chain berkelanjutan yang berorientasi pada ramah lingkungan. Sumberdaya pengetahuan dalam sistem supply chain berkelanjutan merupakan pembangkit bagi value chain pengetahuan yang menunjukkan bagaimana aliran informasi dan pengetahun dapat menemukan pengetahuan baru, mengkonversi dari tacit ke eksplisit, mentransfer pengetahuan melalui dokumentasi dan staf ke staf, dan akhirnya menerapkan pengetahuan tersebut dalam operasional enterprise. Adanya informasi dan pengetahuan dari masyarakat, serta banyaknya permintaan menjadi sumberdaya pengetahuan yang penting dalam supply chian pengetahuan untuk peningkatan berbagai inovasi baru.

Banyak permasalahan yang dapat diidentifikasi dalam sistem informasi supply chain berkelanjutan yang berkaitan pada aspek kelestarian lingkungan. Ada tiga strategi berkelanjutan yang dapat diterapkan untuk mengidentifikasi dan meningkatkan peran sistem informasi supply chain keberlajutan, yaitu penerapan efisiensi, konsistensi dan kecukupan. Sistem informasi supply chain berkelanjutan dapat digunakan untuk mengukur kinerja bisnis secara berkelanjutan. Peranan indeks kinerja bisnis secara berkelanjutan menjadi factor penting sebagai alat untuk mengevaluasi, memantau dan mengendalikan proses kinerja supply chain dalam rangka meningkatkan strategi supply chain untuk menyelarasan dengan strategi proses bisnis enterprise. Indeks kinerja bisnis juga dapat digunakan sebagai alat untuk menghitung kinerja setiap saat secara real time, sehinggga memungkinkan enterprise mendapatkan umpan balik secara terus menerus dari internal dan eksternal, dan manajemen dapat mengambil tindakan perbaikan yang diperlukan untuk hasil yang lebih baik di masa sekarang dan yang akan datang. Penerapan sistem informasi supply chain berkelanjutan bagi enterprise seharusnya tidak dilihat dari aspek biaya saja alam melakukan bisnis, juga harus dipertimbangkan dalam hal peningkatan produktivitas, mengurangi biaya, dan meningkatkan profitabilitas.

\section{Ucapan terima kasih.}

Makalah ini merupakan hasil penelitian yang dibiayai oleh Dana Rutin Program Magister Sistem Informasi Program Pascasarjana Universitas Diponegoro Tahun 2015. Penulis mengucapkan terima kasih kepada Direktur Program Pascasarjana dan Ketua Program Magister Sistem Informasi Program Pascasarjana Universitas Diponegoro. Penulis juga mengucapkan terima kasih kepada Sdr. Daniel Alfa Puryono, yang telah melakukan penelitian tesis dengan judul penerapan green supply 
chain manajemen untuk peningkatan kinerja keuangan perusahaan, sebagai salah satu terapan dari green supply chain.

\section{Daftar Pustaka}

Azevedo S. G., Carvalho H. C., Machado V. C., 2011. The influence of green practices on supply chain performance: A case study approach. Transportation Research Part E 47, 850-871.

Cheng, J. H., Yeh, C. H., Tu, C. W., 2008. Trust and knowledge sharing in green supply chains. Supply Chain Management: An International Journal 13(4), 283-295.

Du Preez, N.D., Low, L., 2007. Managing the knowledge supply chain to support innovation. International Conference on Competitive Manufacturing (COMA).

Elbashir, M.Z., Collier, P.A., Davern, M.J., 2008. Measuring the effects of business intelligence systems: The relationship between business prosess and organizational performance. Int. Journal of Accounting Information Systems 9, 135-153.

Khan, M.Z., Al-Mushayt, O., Alam, J., Ahmad, J., 2010. Intelligent Supply Chain Management, J. Software Engineering \& Applicatons 3, 404408.
Malviya, R.K., Kant, R., 2015. Green supply chain management (GSCM): a stuctured literature review and research implications. Benchmarking : An International Journal, 22 (7) 1360-1394.

Melville, N., 2010. Information systems innovation for Environmental sustainability. MIS Quarterly 34(1), 1-21.

Schaltegger, S., Burritt, B., 2014. Measuring and managing sustainability performance of supply chains, Supply Chain Management: An International Journal, 19(3), 232 - 241

Srivastava, S., 2007. Green supply-chain management: A state-of-the-art literature review. International Journal of Management Reviews 9(1), 53-80.

Tseng, S.M., 2009. A study on customer, supplier, and competitor knowledge using the knowledge chain model. International Journal of Information Management 29, 488-496.

Watson, R. T., Boudreau, M. C., Chen, A. J. Information Systems and Environmentally Sustainable Development: Energy Informatics and New Directions for the IS Community', MIS Quarterly 34 (1), 23-38. 